\section{Research Square}

Preprints are preliminary reports that have not undergone peer review.

They should not be considered conclusive, used to inform clinical practice, or referenced by the media as validated information.

\title{
Knowledge and Surgical Strategies for Successful Laparoscopic Caudate Lobectomy, a Comprehensive Literature Review
}

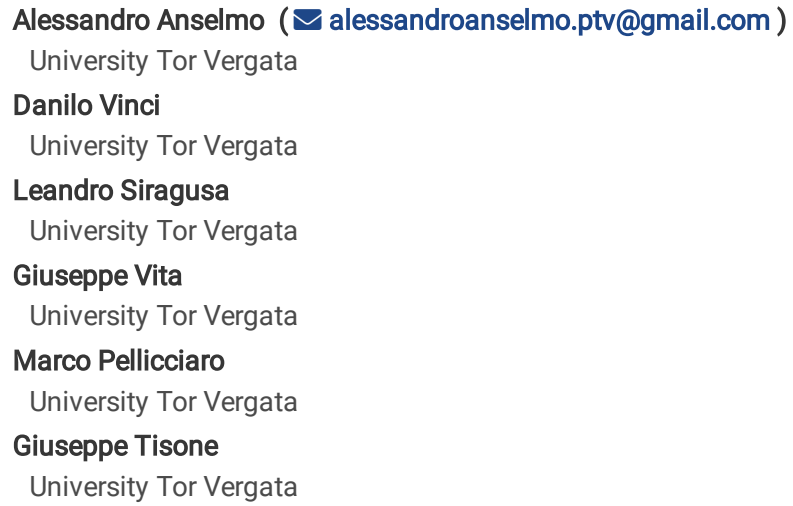

Research Article

Keywords: Caudate lobe, Laparoscopy, Hepatobiliary Surgery

Posted Date: September 28th, 2021

DOI: https://doi.org/10.21203/rs.3.rs-877668/v1

License: (c) (1) This work is licensed under a Creative Commons Attribution 4.0 International License. Read Full License 


\section{Abstract}

Laparoscopic approach in patients presenting caudate lobe lesions has always been considered prohibitive as technically demanding, so that the role of minimally invasive surgery for this posterior and deep location is still debated. Recently some studies presented cases of laparoscopic caudate lobectomy discussing how to manage technical challenges and providing excellent results.

Innovative technologies for laparoscopic liver surgery are likely to improve the feasibility and reproducibility of laparoscopic liver resections in the near future especially for lesions located in the so called "difficult segments".

Still, laparoscopic caudate lobectomy remains unfamiliar to many surgeons and there are relatively few reports in the literature on this subject.

For this reason, we conducted a comprehensive review of the literature to understand the safety and feasibility of LCL resections and discuss current and future perspectives.

\section{Introduction}

In the last decade many reports have demonstrated the feasibility, safety, and adequacy of laparoscopic liver resections (LLRs), which have been widely adopted in many centres throughout the world providing excellent short- and long-term results, comparable to open liver resections [1, 2].

As a consequence, indications for LLRs have increased, including a wide variety of benign and malignant lesions. Nonetheless, the postero-superior segments $(1,4 a, 7$ and 8$)$ are still considered difficult locations, thus requiring expertise and advanced technical skills.

Caudate Lobe (CL) (Couinaud segment I or Spiegel's lobe) is also called dorsal liver and is located posteriorly, below the hepatic hilum, very close to the ductal and portal bifurcation and the hepatic arteries, above the inferior vena cava (IVC). A laparoscopic caudate lobectomy (LCL) can be associated with the resection of other segments for oncological reasons as in the case of right or left hemi-hepatectomy for Klatskin's tumours. An isolate laparoscopic caudate lobectomy (iLCL) is indicated for some symptomatic benign or malignant (primary or secondary) lesions arising in segment I. Some reports address the results of postero-superior LLRs compared with the anterolateral ones, but few papers are exclusively focused on iLCL which accounted for only $2.9 \%$ of 102 LLRs enrolled in a Japanese prospective registry $[3,4]$. iLCL has been described in some case series and case reports from single institutions, but a real standardization of the laparoscopic approach to the dorsal liver, with an appraisal of the technical skills and technology needed, is still lacking among the laparoscopic liver surgeons' community [4-10]. Furthermore, a precise understanding of segment I surgical anatomy and a detailed description of the right border of the caudate process, is crucial in the definition of a real "anatomical resection of caudate lobe". Hereby a comprehensive review of the literature of the last fifteen years analysing the best surgical strategies for a successful laparoscopic caudate lobe resection.

\section{Materials And Methods}

An electronic literature search of the PubMed, Web of Science, and Cochrane databases was performed using the combination of key words: LAPAROSCOPIC, HEPATECTOMY, LIVER RESECTION, CAUDATE LOBE or SEGMENT1. The final search was completed in January 2021. All English language articles related to LLRs were analysed. The references of selected papers were also screened to identify additional publications that might not have been retrieved from the database search. Duplicated data and review articles without original series were excluded. When the results of a single study were reported in more than one publication, only the most recent and complete data were included.

\section{Results}

427 articles were identified, duplicates $(n=101)$, articles not published in English $(n=34)$, and those of obvious irrelevance $(n=210)$, were excluded, leaving 108 articles. Out of these 81 , we excluded review and editorials articles $(n=15)$, articles including a duplication report from the same institution or author $(n=$ $21)$, and articles including extended procedures, other than resection in the posterosuperior segments $(n=24)$. Thus, we finally selected 23 articles about laparoscopic caudate lobe resection. Table 1 shows the flowchart of the literature search.

\section{Concepts of Embryology}

In order to understand surgical anatomy of the liver, we should consider that the caudate lobe and the retro-hepatic vena cava develop as a common entity that is separate from the remaining liver. The dorsal vein, from which the future caudate develops, becomes the portion of inferior vena cava (IVC) between the renal veins and joins the hepato-cardiac channel containing the supra-hepatic veins. The hepatic venous branches to the caudate drain directly into the vena cava, and a few short branches connect the caudate to the main hepatic veins.

As a consequence, segment I should be considered as a "peculiar entity" that is embryologically separate from the rest of the liver [11]. This intimate connection with the IVC and with other important vascular structures, such as the portal bifurcation and the hepatic veins, can explain why the laparoscopic approach to the caudate lobe is still not widely adopted.

\section{History, Surgical Anatomy and the Myth of Segment IX}

In 1989, Couinaud defined the modern segmental anatomy of the liver, with the Spiegel lobe designated as an independent hepatic segment, named as the dorsal sector, caudate lobe, or Couinaud segment I [12]. The caudate lobe lies below the hepatic hilum very close to the ductal and portal bifurcation and the hepatic arteries, above the inferior vena cava. 
According to the most relevant studies published from 1953 to 2000, the caudate lobe can be divided in three main parts or subsegments (Table 2). Kumon's description that includes: the left or Spiegel lobe, the medial pericaval portion, and the right portion or caudate process is the most adopted terminology.

The first and more easily visible portion of segment I at laparoscopic exploration is the Spiegel lobe proper, that can be seen to the left of the IVC through the hepato-gastric ligament, protruding from Arantius sulcus, also called papillary process by Kogure [13].

The birth of "segment IX" myth is due to the fact that Couinaud and Filliponi proposed that the part of the caudate lobe to the right of the middle hepatic vein might be a separate segment: segment IX [14-15]. Further analysis of liver casts showed that the proposed border between pericaval portion of segment I and the postulated segment IX is crossed by overlapping portal pedicles. Given that a portal fissure should not be crossed by any portal pedicle, the same authors propose that the entire dorsal liver should be considered as a single portal segment that has three subsegments: the Spiegel lobe, pericaval portion, and caudate process. So, we believe that the existence of the so-called segment IX is just a myth.

An average of three (one to six) portal branches supply the entire caudate and may arise from the left, right, bifurcation or a combination of the portal branches. A portal branch feeding the paracaval portion of caudate lobe is shown in Fig. 1.

The caudate lobe arteries are multiple small branches arising both from the left and right hepatic artery in about half of individuals, whereas in the rest of the patients a dominant vascularization from left or right can be observed. Venous drainage of segment I is provided by one or two thick veins ( 2 to $3 \mathrm{~mm}$ in diameter), usually called the "caudate veins" (Table 2., Image A) and several thin veins. The thicker veins enter the IVC, the thinner drain into the IVC or the middle and/or right hepatic vein. This network of hepatic veins forms an anastomotic arcade between the main hepatic veins and vena cava, thus providing venous drainage of the dorsal liver even in case of pathologic thrombosis of the main hepatic veins, also called Budd-Chiari Syndrome. Approximately half of the 2 to 4 ducts from the CL join the right posterior sectorial originating from S6 and S7. The other ducts drain into the left hepatic duct [16].

\section{Caudate Lobe Resection in Consensus Conferences, Guidelines and Difficulty Score Systems}

First Consensus Conference on LLS (Louisville, USA 2008), stated that the most favourable indications for the laparoscopic resection was a solitary lesion, 5 $\mathrm{cm}$ or less, located in peripheral liver segments 2 to 6 , whereas lesions located in posterior segments $(1,7$, and 8$)$ were not universally accepted as standard of care [1]. In the Report from the Second International Consensus Conference (Morioka, Japan, 2014) no specific recommendations about LCL are included. Nonetheless, it was agreed that difficulty of the LLR is determined, among others, by the "tumour location and the proximity to major vessels" [2]. During the same Conference, IWATE difficulty scoring system, that is further discussed, have been developed.

The European Guidelines Meeting on Laparoscopic Liver Surgery (Southampton, UK, 2017) included segment I among the so called "difficult segments" (1, 4a, 7, and 8). The expert panel acknowledged that resections of these segments, especially when anatomical, are "highly complex and require advanced expertise in LLR [17]. A new definition of "technically major resection" has been applied to LCLs by Halls in 2018. He stated that, even though posterosuperior segments resections would be considered minor (involving only 1 or 2 Couinaud segments), they involve areas of the liver with a difficult laparoscopic access [18].

Surprisingly a formal LCL was not even included in Ban's novel difficulty scoring system for laparoscopic liver resection published in 2014 [19]. All the same, the author attributed an additional score of 1 to lesions located in proximity of major vessels (main or second branches of Glisson's tree, major hepatic veins and IVC). The original Ban's difficulty scoring system, lacking segment 1 in the tumour location category, had some other limitations such as no separation between segments $4 \mathrm{a}$ and $4 \mathrm{~b}$, and no category for hand-assisted laparoscopic surgery. Because of these limitations, this score was then revised at the Morioka Consensus Conference and renamed the IWATE criteria (an index-based, 4-level classification system) incorporating the difficulty of segment 1 resection (score 4, Fig. 2) [20]. Lately, in 2018, Kawaguchi proposed a new difficulty classification of LLR. In this paper, the LCL is included, among other procedures on posterosuperior segments, in group III, representing highly advanced level of difficulty.

\section{Laparoscopic approach to caudate lobe resection}

LCL has been described in multicentre cohort studies, case series and case reports and our review reports a total of 193 patients (Table 3) [4-10, 20-35].

Laparoscopic resections of lesions located on segment I were shown to be feasible but remain technically demanding procedures which should be performed by experienced laparoscopic hepatic surgeons.

Main indication for CLC included in our review was HCC (36.4\%), followed by benign diseases such hepatolithiasis, focal nodular hyperplasia (FNH) or adenomas (32.6\%); or malignancies like colorectal liver metastasis (CRLM) (21.2\%), unspecified tumours (8.3\%) and cholangiocarcinoma (1.5\%) (Table 4).

It is well recognized that tumor size is a risk factor for conversion or blood loss in laparoscopic liver resection. In 2008 Louisville statement recommended that tumors with larger than $5 \mathrm{~cm}$ in diameter were not candidate for laparoscopic liver resection [39]. Despite this recommendation, in recent years, several reports provided data on laparoscopic approach for larger lesions. There is no agreement in the literature on the maximal tumour dimension suitable for a laparoscopic caudate resection. In patients considered in our review median size of lesions ranged between 12 and $60 \mathrm{~mm}$. Moreover, the possibility of invasion of important structures should be considered in segment l, especially for the paracaval portion [40].

No limitations have been described according to the location of the lesions inside the caudate lobe (caudate process, Spiegel's lobe and paracaval portion). Normally for benign lesions partial resection or CRLM are well accepted while for malignancies such as HCC or cholangiocarcinoma a real anatomical caudate lobectomy is advocated.

On other hand, laparoscopic approach combined with a reverse Trendelenburg position offers a "caudal access" that could provide a better view of liver parenchyma in a narrow surgical field. 
As stated by Cappelle et al. LCL is safe and feasible when performed in high-volume centres. Profound anatomical knowledge, advanced laparoscopic skills, and mastering intraoperative ultrasound are essential [20].

A wide range in operative time and blood loss has been observed among all studies taken into consideration, more likely relating to centre and surgeon experience. No outlying value has been observed and all of them can be considered belonging to an acceptable range of values for hepatic resections.

Conversion to laparotomy has been reported in four patients, representing $2.1 \%$ of this review. One conversion was performed because of difficult localization and enhanced bleeding risk, one as simultaneous resection in segment 4 and 5 could not be delineated by intraoperative ultrasound (IOUS), two for active bleeding (one of which from the IVC).

The oncological radicality achievement was reported in fifteen studies and positive resection margins were observed in 9 patients (7.6\%). For what concerns oncological radicality, as considered in the Cappelle et al. multicentre retrospective study, a negative surgical margin, i.e., $1 \mathrm{~mm}$, is still considered standard [20]. However, in high-volume hepatobiliary units, the occurrence of R1 resection in open caudate lobe resection is reported up to $25 \%$ [43]. Further studies with long-term follow-up are needed in order to evaluate differences between open and laparoscopic approach in terms of negative margin, disease free survival and survival rate.

Morbidity rate reported in the studies included in our review was 5.7\% (11/193) and no mortality was recorded. Complications reported were: three bleedings, three liver insufficiencies, two ascites, one biliary stenosis, one pleural effusion, one surgical site infection and one infective diarrhoea. The results are comparable to the complication rate occurred in open procedures according to a metanalysis by Ding et al [42].

The median length of hospital stay of patients included is 6 days with a range between 3 and 15 days of hospitalization, showing also a postoperative recovery in line with other laparoscopic hepatic procedures and shorter compared to the open approach [42].

\section{Operative techniques and features}

LCL operative techniques and features have been described in multicentre cohort studies, case series and case reports (Table 5) [3-9, 21-36]. All the analysed cases have been carried out laparoscopically. The most used position of the patient was supine with reverse Trendelenburg with an inclination ranging from $15-30 \%$. The exceptions were represented by Ho et al. who suggest a lithotomic position for the patient and Cappelle et al. that reports the use of left lateral position in 2 cases in their multicentre study [21,24]. The number of trocars needed ranged between four and six with the first one placed periumbilically in most cases and still not a standardized position of accessory trocars still placed according to surgeon's preference.

Pringle manoeuvre has been applied for better bleeding control during transection of the hepatic parenchyma in most centres (13/22). Notably encircling the hepatic pedicle also allows better exposition of the operative field by retracting the hepatic hilum to the right or left side depending on the caudate lobe portion to be addressed.

Both left or right approaches are described sharing the same operative steps that can be summarized in: caudate lobe exposure; inflow control by clipping/ligating and dividing the portal triad (Arantius plate dissection is crucial on left side); outflow control by clipping/ligating and dividing the caudate veins draining into IVC (this goal is obtained lifting the caudate lobe and exploiting the laparoscopic caudal view); parenchymal transection. The intraGlissonean approach to caudate lobe pedicles is the most frequent adopted in almost all the studies included in this review. However we found a couple of reports describing the extrahepatic Glissonean approach in laparoscopic caudate lobe resection. Cai et al. [24] dissected and divided caudate portal triads one at a time in their report of an 11 cases series and a laparoscopic anatomic Spiegel lobectomy using a detailed extrahepatic Glissonean approach (with an edited video) has been reported by Xiang et al. [33].

From the technical point of view still is controversial whether to isolate and control the main vascular structures (as the left suprahepatic vein) extrahepatically.

Laparoscopic selective clamping of blood supply for visualization of ischemia demarcation line can be also used in anatomical resection of segment I [37].

Intraoperative ultrasound (IOS) has been used for lesion localization, to outline major vessel proximity and for resection guidance in almost all reviewed cases.

Surgical instruments for laparoscopic surgery have advanced remarkably in recent years, resulting in safer procedures for LLR, even for resection of lesion in difficult segments.

Innovative technologies that have been applied to resections of difficult hepatic segments include: pre-operative 3-D CT-scan reconstructions, ICG green demarcation and use of 3-D laparoscopic equipment. Real-time virtual sonography during liver surgery has been reported recently. This new imaging technology detects the spatial position of an ultrasound probe and reconstructs a section of computed tomography and/or magnetic resonance images in accordance with the ultrasound image [38].

The energy devices used in all series include ultrasonic dissector, radiofrequency, bipolar energy. All used advanced dissectors are listed in Table 3.

Not everyone opted for intraoperative central venous pression (CVP) monitoring. Nonetheless many reports have shown that reduction of cardiac preload leads to a decrease in hepatic vein congestion and reduction of intraoperative blood loss [39-40]. Historically central venous pressure was used to evaluate cardiac preload [39]. More recently, in the era of mini-invasive surgery, stroke volume variation has been reported as a non-invasive approach to guide fluid management. This approach improves intraoperative outcome in laparoscopic liver surgery, thus enhancing the benefits of the minimally-invasive approach and fast-track protocols [41]. 
The site of specimen extraction was either through a trocar enlargement, previous incision and Pfannenstiel incision. Majority, of study reported the use of one the previous incision without specifying site extraction used and according to patients characteristics and surgeon attitude.

\section{Final considerations}

Patients presenting primary hepatic tumours or metastasis in the caudate lobe can easily lose the possibility of radical oncological resection because of the easy and early possibility of the inferior vena cava infiltration, thus it's important to offer them a laparoscopic approach as one of the possible operative techniques. LCL requires a deep anatomic knowledge of the caudate lobe and advanced technical expertise.

As stated by Xu et al., for caudate lobectomy, the laparoscopic technique is a double-edged sword [34]. On one hand, LCL resection can minimize blood loss, decrease post-operative pain and reduces length of the hospital stay, but on the other hand the patient faces the risk of massive intra-operative bleeding and a positive tumour margin. As a result, strict patient selection and experienced surgeons who specialize in both open liver surgery and laparoscopic surgery are needed during this procedure.

A multicenter, propensity score-matched analysis of safety, feasibility and early outcomes in laparoscopic caudate resection performed in eighteen patients reported that laparoscoic approach is a feasible choice for resection of lesions located in segment one with acceptable outcome [42].

Chai et al. affirm that compared with open surgery, the laparoscopic approach could offer a unique viewing angle from below and the superior magnification and illumination could further increase visibility of this visually restricted area, which make laparoscopic isolated complete caudate lobectomy the most ideal oncological resection for tumours confined to the caudate lobe [22].

Ding et al. in a recent metanalysis comparing open and laparoscopic caudate resection found a better postoperative outcome in hospital stay, intraoperative bleeding loss, operation time, and intraoperative blood transfusion requirements, without an increased morbidity rate [43].

Cost-effectiveness analysis of laparoscopic approach compared to the open for CLC is still lacking.

It can be stated that the laparoscopic approach to the caudate lobe is not near future anymore but instead represents the current reality, when considered by high-expertise surgeons working in high-volume hepatobiliary centres. Since the lack of high-quality evidence and the scarcity of cases, prospective clinical trials and multi-centre RCTs are needed in order to standardize this technique.

\section{Abbreviations}

CL caudate lobe

LCL laparoscopic caudate lobectomy

LLR laparoscopic liver resection

iLCL isolate laparoscopic caudate lobectomy

IVC inferior vena cava

FNH focal nodular hyperplasia

CRLM colorectal liver metastases

IOS intraoperative ultrasound

\section{Declarations}

Ethics approval and consent to participate: Informed consent was not applicable to this review. This article does not contain any studies with human participants or animal.

Availability of data and materials: Data supporting reported results are available under requests.

Conflicts of interest: The authors declare no conflict of interest

Funding This research didn't received grants from any founding agency in the public, commercial or not-for-profit sectors.

\section{Authors' contributions:}

A.A and D.V. wrote the manuscript and made substantial direct equal intellectual contribution.

A.A., D.V, L. S., M.P., G.T. have contributed to the conception, design, analysis and/or interpretation of data and they made substantial intellectual contribution. G.T. critically revised the manuscript.

All authors have read and agreed to the published version of the manuscript. 
Aknowledgements: The authors want to thanks the editor and reviewers.

\section{References}

[1] Buell JF, Cherqui D, Geller DA, O'Rourke N, lannitti D, Dagher I et al (2009) Position on laparoscopic liver surgery. Ann Surg. doi:10.1097/sla.0b013e3181b3b2d8

[2] Wakabayashi G, Cherqui D, Geller DA, Buell JF, Kaneko H, Ho Seong Han et al (2015). Recommendations for laparoscopic liver resection. Consensus Conference Morioka. Ann Surg. doi: 10.1097/SLA.0000000000001184

[3] Fuji H, Hatano E, Seo S, Arimoto A, Okabe M, Fujikawa T et al (2017) Prospective registry for laparoscopic liver resection. Asian J Endosc Surg. doi: $10.1111 /$ ases. 12351

[4] Araki K, Fuks D, Nomi T, Ogiso S, Lozano RR, Kuwano H et al (2016) Feasibility of laparoscopic liver resection for caudate lobe: technical strategy and comparative analysis with anteroinferior and posterosuperior segments. Surg Endosc. doi: 10.1007/s00464-016-4747-7

[5] Dulucq JL, Wintringer P, Stabilini C, Mahajna A (2006) Isolated laparoscopic resection of the hepatic caudate lobe: surgical technique and a report of 2 cases. Surg Laparosc Endosc Percutan Tech. doi: 10.1097/01.sle.0000202183.27042.63

[6] Koffron AJ, Auffenberg G, Kung R, Abecassis M (2007) Evaluation of 300 minimally invasive liver resections at a single institution: less is more. Ann Surg. doi: 10.1097/SLA.0b013e318146996c

[7] Chen KH, Jeng KS, Huang SH, Chu SH (2013) Laparoscopic caudate hepatectomy for cancer-an innovative approach to the no-man's land. J Gastrointest Surg. doi: 10.1007/s11605-012-2115-z

[8] Lai EC, Tang CN (2014) Robot-assisted laparoscopic partial caudate lobe resection for hepatocellular carcinoma in cirrhotic liver. Surg Laparosc Endosc Percutan Tech. doi: 10.1097/SLE.0b013e31829ce820

[9] Salloum C, Lahat E, Lim C, Doussot A, Osseis M, Compagnon P et al (2016) Laparoscopic isolated resection of caudate lobe (segment 1): a safe and versatile technique. J Am Coll Surg. doi: 10.1016/j.jamcollsurg.2016.01.047

[10] Oh D, Kwon CH, Na BG, Lee KW, Cho WT, Lee SH et al (2016) Surgical Techniques for Totally Laparoscopic Caudate Lobectomy. J Laparoendosc Adv Surg Tech A. doi: 10.1089/lap.2016.0161

[11] Lassau JP,Hureau J (1968) Note on the organogenesis of the retro-hepatic segment of the vena cava in humans. CR Ass Anat.

[12] Couinaud C (1966) Plea for exact hepatic segmentation and an anatomic technic of regular resection of the liver: partial clamping of the hepatic stump. Presse Med.

[13] Kogure K, Kuwano H, Fujimaki N, Makuuchi M. Relation among portal segmentation, proper hepatic vein, and external notch of the caudate lobe in the human liver. Ann Surg. doi: 10.1097/00000658-200002000-00011

[14] Filipponi F, Romagnoli P, Mosca F, Couinaud C (2000) The dorsal sector of human liver: embryological, anatomical and clinical relevance. Hepatogastroenterology.

[15] Couinaud C (1994) Intrahepatic anatomy: application to liver transplantation. Ann Radiol.

[16] Abdalla EK, Vauthey JN, Couinaud (2003) The caudate lobe of the liver: implications of embryology and anatomy for surgery. Surg Oncol Clin N Am. 2002 doi: 10.1016/s1055-3207(02)00035-2

[17] Abu Hilal M, Aldrighetti L, Dagher I, Edwin B, Troisi RI, Alikhanov R et al (2017) The Southampton consensus guidelines for laparoscopic liver surgery: from indication to implementation. Ann Surg. doi: 10.1097/SLA.0000000000002524

[18] M. C. Halls, G. Berardi, F. Cipriani et al (2018) Development and validation of a difficulty score to predict intraoperative complications during laparoscopic liver resection. Br J Surg. doi: 10.1002/bjs.10821

[19] Ban D, Tanabe M, Ito H, Otsuka Y, Nitta H, Abe Y et al (2014) A novel difficulty scoring system for laparoscopic liver resection. J Hepatobiliary Pancreat Sci. doi: 10.1002/jhbp.166

[20] Tanaka S, Kawaguchi Y, Kubo S, Kanazawa A, Takeda Y, Hirokawa F et al (2019) Validation of index-based IWATE criteria as an improved difficulty scoring system for laparoscopic liver resection. Surgery. doi: 10.1016/j.surg.2018.10.012

[21] Cappelle M, Aghayan DL, van der Poel MJ, Besselink MG, Sergeant G, Edwin B et al (2020) A multicenter cohort analysis of laparoscopic hepatic caudate lobe resection. Langenbeck's Arch Surg. doi: 10.1007/s00423-020-01867-2

[22] Chai S, Zhao J, Zhang Y, Xiang S, Zhang W (2018) Arantius ligament suspension: A novel technique for retraction of the left lateral lobe liver during laparoscopic isolated caudate lobectomy. J Laparoendosc Adv Surg Tech. doi: 10.1089/lap.2017.0572 
[23] Hayami S, Ueno M, Kawai M, Miyamoto A, Suzaki N, Hirono S et al (2019) Standardization of surgical procedures for laparoscopic Spiegel lobectomy: A single-institutional experience. Asian J Endosc Surg. doi: 10.1111/ases.12609

[24] Ho KM, Han HS, Yoon YS, Cho JY, Choi YR, Jang JS et al (2017) Laparoscopic Total Caudate Lobectomy for Hepatocellular Carcinoma. J Laparoendosc Adv Surg Tech. doi: 10.1089/lap.2016.0459

[25] Jin B, Jiang Z, Hu S, Du G, Shi B, Kong D et al (2018) Surgical Technique and Clinical Analysis of Twelve Cases of Isolated Laparoscopic Resection of the Hepatic Caudate Lobe. Biomed Res Int. doi: 10.1155/2018/5848309

[26] Koh YX, Lee SY, Chiow AKH, Kam JH, Goh BKP, Chan CY. (2017) Laparoscopic caudate lobe resection: navigating the technical challenge. Ann Laparosc Endosc Surg.

[27] Li Y, Zeng KN, Ruan DY, et al. (2019) Feasibility of laparoscopic isolated caudate lobe resection for rare hepatic mesenchymal neoplasms. World J Clin Cases.

[28] Liu F, Wei Y, Li B. (2019) Laparoscopic Isolated Total Caudate Lobectomy for Hepatocellular Carcinoma Located in the Paracaval Portion of the Cirrhotic Liver. Ann Surg Oncol.

[29] Machado MA, Surjan R, Bassères T, Makdissi F. (2018) Laparoscopic resection of caudate lobe. Technical strategies for a difficult liver segment - Video article. Surg Oncol.

[30] Siming Z, Jie Z, Hong L, Haibiao W. (2020) Laparoscopic caudate lobe resection for the treatment of hepatolithiasis. J Minim Access Surg.

[31] Vega EA, Nicolaescu DC, Salehi O, et al. (2020) Laparoscopic Segment 1 with Partial IVC Resection in Advanced Cirrhosis: How to Do It Safely. Ann Surg Oncol.

[32] Wan HF, Xie KL, Li JX, Ho KM, Wu H, Huang JW. (2020) Laparoscopic Caudate Lobectomy for Cholangiocarcinoma of Caudate Lobe Invading Middle Hepatic Vein. Ann Surg Oncol.

[33] Xiang S, Zhang YX, Chai SS, Zhang WG. (2019) Laparoscopic Anatomic Spiegel Lobectomy with the Extrahepatic Glissonean Approach. Surg Laparosc Endosc Percutaneous Tech.

[34] Xu G, Tong J, Ji J, et al. (2020) Laparoscopic caudate lobectomy: a multicenter, propensity score-matched report of safety, feasibility, and early outcomes. Surg Endosc.

[35] Ding Z, Huang Y, Liu L, Xu B, Xiong H, Luo D, Huang M. (2020) Comparative analysis of the safety and feasibility of laparoscopic versus open caudate lobe resection. Langenbecks Arch Surg.

[36] Peng Y, Liu F, Xu H, Guo S, Wei Y, Li B. (2020) Propensity score matching analysis for outcomes of laparoscopic versus open caudate lobectomy. ANZ J Surg.

[37] Zhuo LW, Prasoon P, Wu H. (2014) Role of vascular clamping in hepatic resection: a review. Hepatogastroenterology.

[38] Satou S, Aoki T, Kaneko J, Sakamoto Y, Hasegawa K, Sugawara Y et al (2014) Initial experience of intraoperative three-dimensional navigation for liver resection using real-time virtual sonography. Surgery. doi: 10.1016/j.surg.2013.08.009

[39] Smyrniotis V, Kostopanagiotou G, Theodoraki K, Tsantoulas D, Contis JC.(2004) The role of central venous pressure and type pf vascular control inblood loss during major hepatic resections.Am J Surg.

[40] Melendez JA, Arslan V, Fisher ME, Wuest D, Jarnagin WR, Fong Yet al (1998) Perioperative outcomes of major hepatic resections under lowcentral venous pressure anesthesia: blood loss, blood transfusion, andthe risk of postoperative renal dysfunction.J Am Coll Surg.

[41] Ratti F, Cipriani F, Reineke R, Catena M, Paganelli M, Comotti L et al (2016) Intraoperative monitoring of stroke volume variation versus central venous pressure in laparoscopic liver surgery: a randomized prospective comparative trial. HPB (Oxford).

[42]Xu G, Tong J, Ji J, Wang H, Wu X, Jin B et al (2021) Laparoscopic caudate lobectomy: a multicenter, propensity score-matched report of safety, feasibility, and early outcomes. Surg Endosc. doi: 10.1007/s00464-020-07478-8

[43] Ding Z, Liu L, Xu B, Huang Y, Xiong H, Luo D, Huang M. (2021) Safety and feasibility for laparoscopic versus open caudate lobe resection: a meta-analysis. Langenbecks Arch Surg. doi: 10.1007/s00423-020-02055-y

[44] Healey JJ, Schroy PC (1953) Anatomy of the biliary ducts within the human liver; analysis of the prevailing pattern of branchings and the major variations of the biliary ducts. AMA Arch Surg. doi:10.1001/archsurg.1953.01260030616008.

[45] Couinaud C. (1981) Controlled Hepatectomies and Exposure of the Intrahepatic Bile Ducts: Anatomical and Technical Study.

[46] Kumon M, Kumon T, Tsutsui E, Ebashi C, Namikawa T, Ito K, Sakamoto Y. (2020) Definition of the caudate lobe of the liver based on portal segmentation. Glob Health Med. doi: 10.35772/ghm.2020.01088 
[47] Elias D, Lasser PH, Desruennes E, Mankarios H, Jiang Y. (1992) Surgical approach to segment I for malignant tumors of the liver. Surg Gynecol Obstet. Jul;175(1):17-24.

[48] Couinaud C. (1998) Secteur dorsal du foie [Dorsal sector of the liver]. Chirurgie. doi: 10.1016/s0001-4001(98)80033-0.

[50] Kogure K, Kuwano H, Fujimaki N, Makuuchi M. (2000) Relation among portal segmentation, proper hepatic vein, and external notch of the caudate lobe in the human liver. Ann Surg. doi: 10.1097/00000658-200002000-00011

[51] Wakabayashi G (2016) What has changed after the Morioka consensus conference 2014 on laparoscopic liver resection? Hepatobiliary Surg Nutr.

\section{Tables}

Due to technical limitations, table 1, 2 \& 4 is only available as a download in the Supplemental Files section.

Table 3. Published case series of isolate laparoscopic caudate lobectomy (LCL) 


\begin{tabular}{|c|c|c|c|c|c|c|c|c|c|c|}
\hline & $\begin{array}{l}\text { Number } \\
\text { of } \\
\text { patients }\end{array}$ & Indications & $\begin{array}{l}\text { Subsegment of } \\
\text { Caudate Lobe } \\
\text { Resected }\end{array}$ & $\begin{array}{l}\text { Median } \\
\text { Lesion } \\
\text { Size } \\
(\mathrm{mm})\end{array}$ & $\begin{array}{l}\text { Blood } \\
\text { Loss } \\
(\mathrm{ml})\end{array}$ & $\begin{array}{l}\text { Median } \\
\text { Operation } \\
\text { Time } \\
\text { (Min) }\end{array}$ & $\begin{array}{l}\text { Morbidity } \\
\text { Rate }\end{array}$ & $\begin{array}{l}\text { Complications } \\
\text { (General and } \\
\text { Liver Specific) }\end{array}$ & $\begin{array}{l}\text { Laparotomy } \\
\text { Conversion }\end{array}$ & $\begin{array}{l}\text { Days of } \\
\text { Hospitalization }\end{array}$ \\
\hline $\begin{array}{l}\text { Dulucq et } \\
A l^{3}\end{array}$ & 2 & 2 CRLM & - & - & 150 & 127 & - & - & 0 & 9 \\
\hline $\begin{array}{l}\text { Koffron } \\
\text { et } A{ }^{4} .^{4}\end{array}$ & 7 & HCC, benign & - & - & - & - & - & - & 0 & - \\
\hline $\begin{array}{l}\text { Chen et } \\
A l .^{5}\end{array}$ & 8 & $\begin{array}{l}4 \mathrm{HCC} \text {, } \\
\text { 4metastases }\end{array}$ & CP, SL, PC & - & 110 & 248 & - & - & 0 & 6.9 \\
\hline $\begin{array}{l}\text { Lai And } \\
\text { Tang }^{6}\end{array}$ & 2 & $2 \mathrm{HCC}$ & - & 15 & 143 & 143 & - & - & 0 & 4.5 \\
\hline $\begin{array}{l}\text { Araki et } \\
\text { Al. }{ }^{7}\end{array}$ & 15 & $\begin{array}{l}\text { HCC, } \\
\text { metastases, } \\
\text { benign }\end{array}$ & CP, SL, PC & 19.5 & 75 & 150 & $6.6 \%$ & $\begin{array}{l}\text { BS, BL } \\
\text { (massive from } \\
\text { major } \\
\text { vessels) }\end{array}$ & 0 & 8 \\
\hline $\begin{array}{l}\text { Salloum } \\
\text { et } A I^{8}\end{array}$ & 5 & $\begin{array}{l}4 \mathrm{HCC}, 1 \\
\text { benign }\end{array}$ & CP, SL, PC & 35 & 200 & 240 & - & - & 0 & 6 \\
\hline Oh et $A{ }^{9}{ }^{9}$ & 6 & $\begin{array}{l}4 \mathrm{HCC}, 1 \mathrm{CC}, \\
1 \text { metas- } \\
\text { tases }\end{array}$ & $\mathrm{CP}, \mathrm{SL}, \mathrm{PC}$ & 26.5 & 242.5 & 382 & - & - & 0 & 8 \\
\hline $\begin{array}{l}\text { Cappelle } \\
\text { et } A I^{20}\end{array}$ & 32 & $\begin{array}{l}22 \text { CRLM, } 1 \\
\text { CC, } 4 \\
\text { unspecifid } \\
\text { malign } \\
\text { lesion, } 5 \\
\text { benign }\end{array}$ & SL, PC, SL & 22 & 100 & 155 & $6.3 \%$ & $1 \mathrm{BL}, 1 \mathrm{LI}$ & $9.4 \%$ & 3 \\
\hline $\begin{array}{l}\text { Chai et } \\
A l .^{21}\end{array}$ & 6 & $\mathrm{CV}, \mathrm{HCC}$ & - & 54 & 260 & 249 & - & $\begin{array}{l}1 \text { surgical site } \\
\text { infection, } 1 \\
\text { pleural } \\
\text { effusion }\end{array}$ & 0 & 7 \\
\hline $\begin{array}{l}\text { Hayami } \\
\text { et } A{ }^{22}\end{array}$ & 6 & HCC, CRCM & - & 18.3 & 35 & 207 & - & - & 0 & 8 \\
\hline $\begin{array}{l}\text { Ho et } \\
A l .^{23}\end{array}$ & 1 & $\mathrm{HCC}$ & & 16 & 200 & 270 & - & - & 0 & 4 \\
\hline $\begin{array}{l}\text { Jin et } \\
A l^{24}\end{array}$ & 12 & $\begin{array}{l}\mathrm{CH}, \mathrm{HCC}, \\
\mathrm{FNH}\end{array}$ & $\mathrm{CP}$ & 55 & 97 & 140 & - & - & 0 & 9.2 \\
\hline $\begin{array}{l}\text { Koh et } \\
A l^{25}\end{array}$ & 6 & HCC, CRLM & - & 30 & 217 & 318 & - & - & 0 & 4 \\
\hline Li et $A l^{26}$ & 11 & $\begin{array}{l}\text { MT, HCC, } \\
\text { FNH }\end{array}$ & - & 33 & 133 & 226 & - & - & 0 & 6 \\
\hline $\begin{array}{l}\text { Liu et } \\
A l .^{27}\end{array}$ & 1 & $\mathrm{HCC}$ & PC & 25 & - & 300 & - & - & 0 & - \\
\hline $\begin{array}{l}\text { Machado } \\
\text { et } A I^{28}\end{array}$ & 1 & CRLM & - & - & $<50$ & 120 & - & - & 0 & 3 \\
\hline $\begin{array}{l}\text { Siming et } \\
A I^{29}\end{array}$ & 9 & $\mathrm{HL}$ & - & - & 530 & 310 & - & $1 \mathrm{BL}$ & 0 & 10 \\
\hline $\begin{array}{l}\text { Vega et } \\
A l^{30}\end{array}$ & 1 & $\mathrm{HCC}$ & SL & 36 & - & - & - & - & 0 & - \\
\hline $\begin{array}{l}\text { Wan et } \\
\mathrm{Al}^{31}\end{array}$ & 1 & $\mathrm{CC}$ & - & 42 & 180 & 300 & - & - & 0 & 7 \\
\hline $\begin{array}{l}\text { Xiang et } \\
A{ }^{32}\end{array}$ & 1 & $\mathrm{HCC}$ & SL & - & $<50$ & 196 & - & - & 0 & 6 \\
\hline $\begin{array}{l}\text { Xu et } \\
A l^{33}\end{array}$ & 19 & $\begin{array}{l}\mathrm{CH}, \mathrm{FNH}, \mathrm{AD}, \\
\mathrm{HCC}, \mathrm{CRLM}\end{array}$ & $\mathrm{CL}, \mathrm{SL}, \mathrm{PC}$ & 11.9 & 75 & 186.5 & - & - & 0 & 6 \\
\hline
\end{tabular}




\begin{tabular}{|c|c|c|c|c|c|c|c|c|c|c|}
\hline $\begin{array}{l}\text { Ding et } \\
\text { al. } 34\end{array}$ & 10 & $\begin{array}{l}5 \text { HCC, } 5 \\
\text { Benign }\end{array}$ & $10 \mathrm{CL}$ & 60 & 50 & 216 & - & - & - & 15 \\
\hline $\begin{array}{l}\text { Peng et } \\
\text { al. }^{35}\end{array}$ & 31 & $\begin{array}{l}10 \text { HCC, } 4 \\
\text { CRLM, } 17 \\
\text { Benign }\end{array}$ & $\begin{array}{l}5 \mathrm{SL}, 1 \mathrm{SL}+\mathrm{PC}, 4 \\
\mathrm{PL}+\mathrm{PC}, 1 \\
\text { SL+PL+PC, } \\
\text { 20Tumorectomy }\end{array}$ & 40 & 100 & 210 & $516.1 \%$ & $\begin{array}{l}1 \text { infectious } \\
\text { dhiarrhea, } 2 \\
\text { LI, } 2 \text { Ascitis }\end{array}$ & $3.2 \%$ & 5 \\
\hline
\end{tabular}

HCC hepatocellular carcinoma, CC Cholangiocarcinoma, BD Benign Disease, CRCM Colo-rectal cancer metastases, CH Cavernous Hemangioma, FNH Focal Nodular Hyperplasia, MT Mesenchymal tumours, HL Hepatolithiasis, AD Adenoma, CP caudate process, SL Spiegel's lobe, PC pericaval portion, BL Biliary Leakage, BS Biliary Stenosis, BL Bleeding, LI Liver Insufficiency.

Table 5. Technical and operating features of the published case series of isolate laparoscopic caudate lobectomy (LCL) 


\begin{tabular}{|c|c|c|c|c|c|c|c|}
\hline & $\begin{array}{l}\text { Number of } \\
\text { patients }\end{array}$ & $\begin{array}{l}\text { Operative } \\
\text { Setting }\end{array}$ & Patient Position & Trocars & $\begin{array}{l}\text { CVP Intraoperative } \\
\text { Management }\end{array}$ & $\begin{array}{l}\text { Pringle } \\
\text { Manoeuvre }\end{array}$ & Energy Devices \\
\hline $\begin{array}{l}\text { Dulucq et } \\
\text { al. }^{3}\end{array}$ & 2 & Lps & Supine with split legs & $\begin{array}{l}6 \\
\text { trocars }\end{array}$ & Yes $(5 \mathrm{mmHg})$ & Yes & $\begin{array}{l}\text { Ligasure and } \\
\text { DISSECTRON }\end{array}$ \\
\hline $\begin{array}{l}\text { Koffron Et } \\
\text { Al. }{ }^{4}\end{array}$ & 7 & Lps & Supine & - & Yes & - & Ligasure \\
\hline $\begin{array}{l}\text { Chen et } \\
\text { Al. } .^{5}\end{array}$ & 8 & Lps & Modified Lithotomy Position & $\begin{array}{l}4 \text { or } 5 \\
\text { trocars }\end{array}$ & - & - & Harmonic \\
\hline $\begin{array}{l}\text { Lai And } \\
\text { Tang }^{6}\end{array}$ & 2 & $\begin{array}{l}\text { Lps (Robot- } \\
\text { Assisted) }\end{array}$ & $\begin{array}{l}\text { Supine with split legs and reverse } \\
\text { Trendelenburg }\end{array}$ & $\begin{array}{l}5 \\
\text { trocars }\end{array}$ & Yes $(<5 \mathrm{mmHg})$ & - & - \\
\hline $\begin{array}{l}\text { Araki et } \\
\text { Al. }^{7}\end{array}$ & 15 & Lps & - & - & - & - & $\begin{array}{l}\text { Harmonic and } \\
\text { Thunderbeat }\end{array}$ \\
\hline $\begin{array}{l}\text { Salloum et } \\
\text { Al. }^{8}\end{array}$ & 5 & Lps & $\begin{array}{l}\text { Supine with split legs and reverse } \\
\text { Trendelenburg }\end{array}$ & $\begin{array}{l}6 \\
\text { trocars }\end{array}$ & Yes $(<5 \mathrm{mmHg})$ & Yes & $\begin{array}{l}\text { Ligasure and } \\
\text { DISSECTRON }\end{array}$ \\
\hline Oh et Al. ${ }^{9}$ & 6 & Lps & Modified Lithotomy Position & $\begin{array}{l}5 \\
\text { trocars }\end{array}$ & - & - & - \\
\hline $\begin{array}{l}\text { Cappelle } \\
\text { et al. }{ }^{20}\end{array}$ & 32 & Lps & $\begin{array}{l}\text { Supine in } 30^{\circ} \text { reverse } \\
\text { Trendelenburg }\end{array}$ & $\begin{array}{l}4 \text { or } 5 \\
\text { trocars }\end{array}$ & Yes & Yes & $\begin{array}{l}\text { ENSEAL and } \\
\text { CUSA }\end{array}$ \\
\hline $\begin{array}{l}\text { Chai et } \\
\text { al. }{ }^{21}\end{array}$ & 6 & Lps & Supine with closed legs & $\begin{array}{l}5 \\
\text { trocars }\end{array}$ & - & Yes & - \\
\hline $\begin{array}{l}\text { Hayami et } \\
\text { al. }^{22}\end{array}$ & 6 & Lps & $\begin{array}{l}\text { Supine with open legs in } 15^{\circ} \\
\text { reverse Trendelenburg }\end{array}$ & $\begin{array}{l}5 \\
\text { trocars }\end{array}$ & - & Yes & $\begin{array}{l}\text { Harmonic ACE } \\
\text { and CUSA }\end{array}$ \\
\hline Ho et al. ${ }^{23}$ & 1 & Lps & Lithotomy position & $\begin{array}{l}5 \\
\text { trocars }\end{array}$ & - & - & $\begin{array}{l}\text { Harmonic, } \\
\text { Ligasure and } \\
\text { CUSA }\end{array}$ \\
\hline Jin et al. ${ }^{24}$ & 12 & Lps & Supine in $30^{\circ}$ reverse & $\begin{array}{l}6 \\
\text { trocars }\end{array}$ & - & Yes & - \\
\hline $\begin{array}{l}\text { Koh et } \\
\text { al. }^{25}\end{array}$ & 6 & Lps & Supine with split legs & $\begin{array}{l}5 \\
\text { trocars }\end{array}$ & Yes $(5 \mathrm{mmHg})$ & Yes & CUSA \\
\hline Li et al. ${ }^{26}$ & 11 & Lps & Supine & $\begin{array}{l}5 \\
\text { trocars }\end{array}$ & Yes $(<5 \mathrm{mmHg})$ & Yes & Harmonic \\
\hline Liu et al. ${ }^{27}$ & 1 & Lps & Supine & - & - & Yes & $\begin{array}{l}\text { Harmonic, } \\
\text { Ligasure and } \\
\text { CUSA }\end{array}$ \\
\hline $\begin{array}{l}\text { Machado } \\
\text { et al. }{ }^{28}\end{array}$ & 1 & Lps & - & $\begin{array}{l}4 \\
\text { trocars }\end{array}$ & - & - & Bipolar \\
\hline $\begin{array}{l}\text { Siming et } \\
\text { al. }\end{array}$ & 9 & Lps & Supine with split legs & $\begin{array}{l}5 \\
\text { trocars }\end{array}$ & - & - & - \\
\hline $\begin{array}{l}\text { Vega et } \\
\text { al. }^{30}\end{array}$ & 1 & Lps & Supine with split legs & - & Yes & - & - \\
\hline $\begin{array}{l}\text { Wan et } \\
\text { al. }{ }^{31}\end{array}$ & 1 & Lps & Supine with split legs & $\begin{array}{l}5 \\
\text { trocars }\end{array}$ & Yes $(<5 \mathrm{mmHg})$ & Yes & $\begin{array}{l}\text { Harmonic, ACE } \\
\text { and CUSA }\end{array}$ \\
\hline $\begin{array}{l}\text { Xiang et } \\
\text { al. }{ }^{32}\end{array}$ & 1 & Lps & Supine with split legs & $\begin{array}{l}5 \\
\text { trocars }\end{array}$ & Yes & - & - \\
\hline Xu et al. ${ }^{33}$ & 19 & Lps & Supine with split legs & $\begin{array}{l}5 \\
\text { trocars }\end{array}$ & Yes $(<5 \mathrm{mmHg})$ & Yes & CUSA \\
\hline $\begin{array}{l}\text { Ding et al. } \\
34\end{array}$ & 10 & Lps & Supine with split legs & $\begin{array}{l}5 \\
\text { trocars }\end{array}$ & $\begin{array}{l}\text { Yes (between 4-6 } \\
\mathrm{mmHg} \text { ) }\end{array}$ & Yes & $\begin{array}{l}\text { Ultrasonic } \\
\text { scalpel }\end{array}$ \\
\hline $\begin{array}{l}\text { Peng et } \\
\text { al. }^{35}\end{array}$ & 31 & Lps & Supine & $\begin{array}{l}5 \\
\text { trocars }\end{array}$ & Yes $(<5 \mathrm{mmHg})$ & Yes & $\begin{array}{l}\text { Harmonic, } \\
\text { Ligasure and } \\
\text { CUSA }\end{array}$ \\
\hline
\end{tabular}




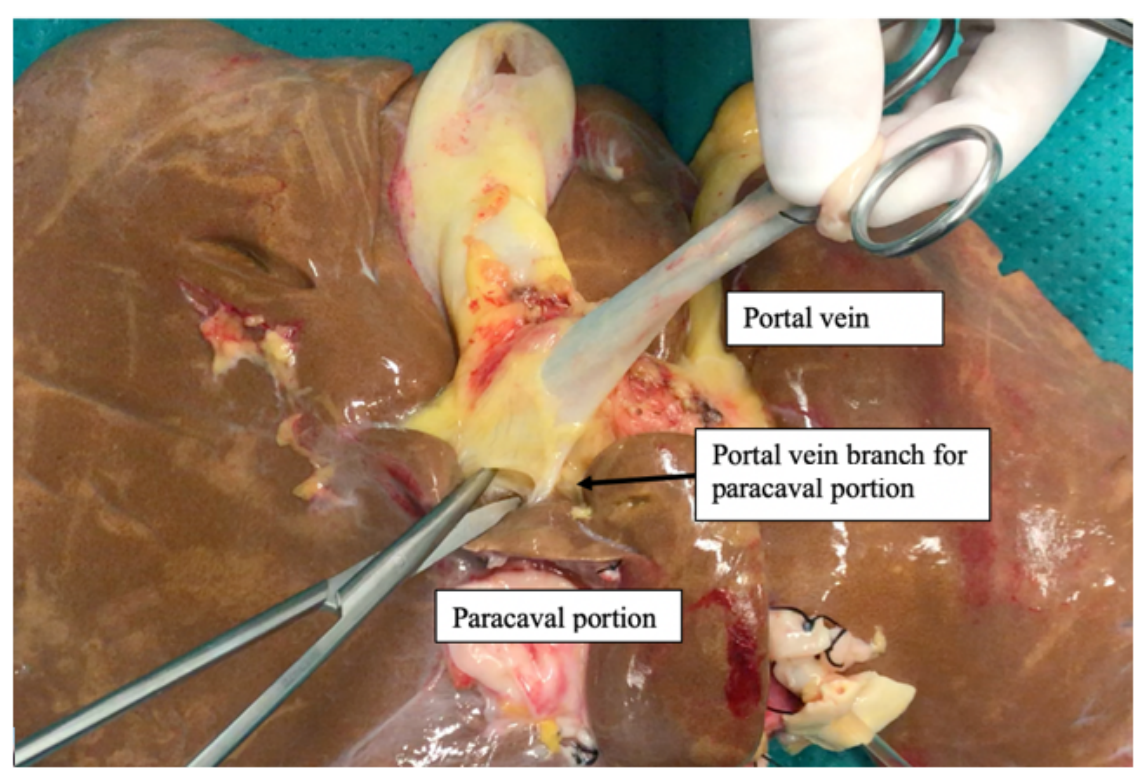

Figure 1

Portal supply of the paracaval portion of caudate lobe

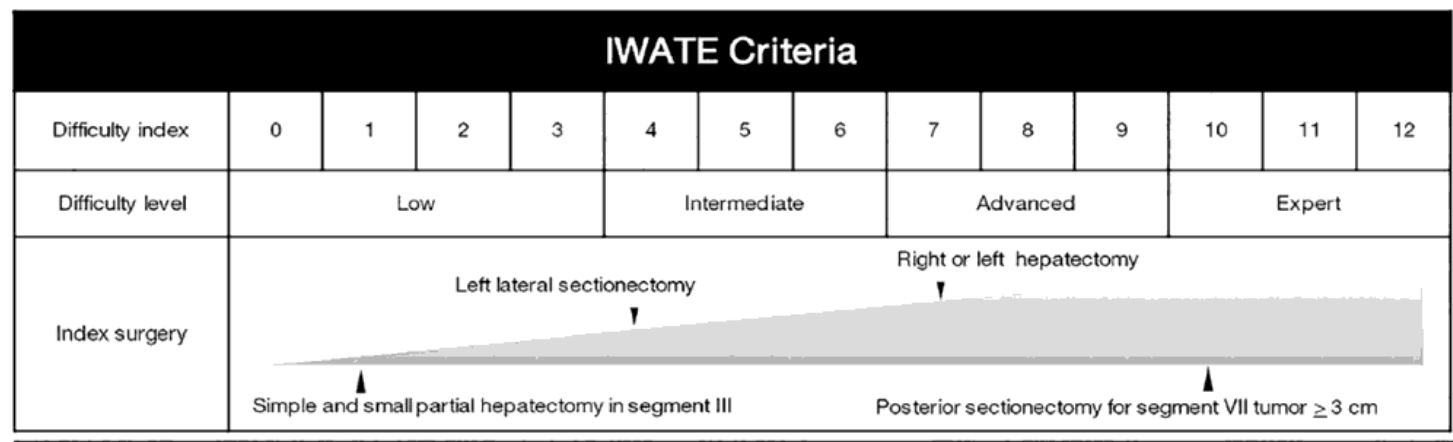

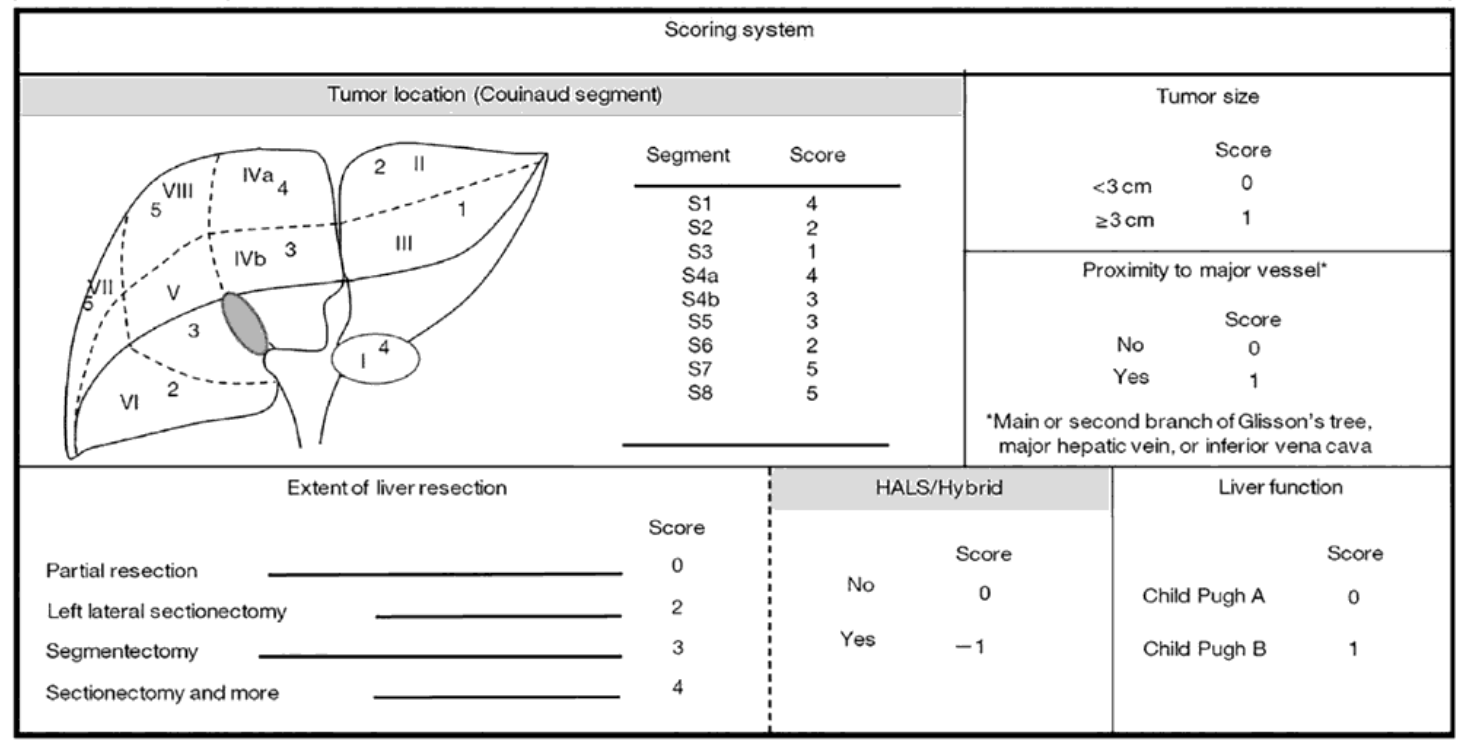

Fig. 1. IWATE criteria proposed at the 2nd International Consensus Conference on Laparoscopic Liver Resection as an improved difficulty scoring system (Reprinted from Wakabayashi, ${ }^{10}$ with permission from the AME Publishing Company. Hong Kong). (Top) The difficulty level was ranked on a scale of $0-12$ on the basis of expert assessments between ste

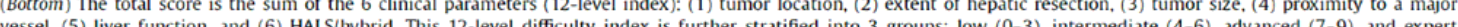
(10-12) (4-level difficulties)

\section{Figure 2}

Iwate Criteria [51] 


\section{Supplementary Files}

This is a list of supplementary files associated with this preprint. Click to download.

- table1.docx

- table2.docx

- table4.docx 